Derfor kan og bør enhver med interesse $\mathrm{i}$ feltet tage notits af disse bidrag.

MAGNUS BIRK CLAUSEN

\section{Filosofi og hjerneforskning}

Steen Nepper Larsen: PHILOSOPHY MATTERS! Samtidsdiagnostiske tydninger i den plastiske hjernes ara, GNOSIS, 2009, 125 sider, frit tilgangelig som e-bog på www.gnosis.au.dk, eller kontak.t GNOSIS for tilsendelse.

Det er ikke uden grund, at titlen på det femte nummer i serien GNOSIS Vedhæftninger er skrevet med store bogstaver og efterfølges af et udråbstegn. Steen Nepper Larsen mener det alvorligt, når han programmatisk hævder og gennem bogen understreger filosofiens relevans for hjerneforskningen og navnlig for samfundsteoriens syn på sidstnævnte. Det er ifølge forfatteren et nødvendigt opråb, da filosofien ofte anses for irrelevant i forbindelse med hjerneforskningen, der selv synes at kunne levere svarene, mens samfundsteorien helt forviser filosofien fra dette felt, idet den anklager filosofferne for at overkomplicere sagen. Gennem bogen viser Larsen, hvordan og hvorfor filosofien er relevant $i$ forbindelse med hjerneforskningen, og han udfolder ikke mindst sit bud på en kortlægning af de filosofiske problematikker på dette felt. En kortlægning, der samtidig fungerer som en udmærket introduktion til hjerneforskningen som filosofisk felt.

Som det pointeres $\mathrm{i}$ indledningen til bogen er Larsens filosofiske udgangspunkt forholdet mellem "hjerne og bevidsthed" samt forholdet mellem "hjerneprocesser og tænkning”, og dette anvendes som springbræet til de i undertitlen proklamerede "samtidsdiagnostiske tydninger". Undervejs i bogen blottes der imidlertid en mindre kløft mellem den filosofiske diskussion af hjernen og hjerneforskningens samfundsmæssige betydning i dag. En kløft som Larsen forsøger at bygge bro over med Leslie Brothers' teori om “den sociale hjerne” (kap.7). Men resultaterne af de indledende filosofiske øvelser om bevidsthed og tænkning er udpræget fraværende i samtidsdiagnostikken og skinner intetsteds igennem, ligesom den bro, Larsen anvender til at krydse kløften, så at sige viser sig allerede at være brændt: Teorien om den sociale hjerne var oprindeligt en filosofisk kritik af neurocentrismen, men er i dag blevet neutraliseret og indoptaget af neurovidenskaben, en af Larsens hovedpointer. Det kløver 
bogen lidt $\mathrm{i}$ to, men heldigvis holdes den sammen af Larsens kartografiske proces.

Kortlægningen undervejs gennem de første ni kapitler fungerer glimrende, og forfatteren virker velbevandret på området, selvom vi kun introduceres for et begrænset udvalg. En af hovedårsagerne til at denne kortlægning fungerer så godt er dens rhizomatiske præg. Selvom Larsen anbefaler at læse bogen lineært (hvilket jeg her vil istemme), er bogens enkelte kapitler selvstændige ruter, man på sin vis godt kunne følge i vilkårlig rækkefølge. Det betyder, at man som læser føres igennem blindgyder og kringelkroge, afsøger grænser og forladte stier, der til slut danner skitsen til et kort over hjerneforskningens filosofiske problemfelt. At visse dele stritter, ligesom nogle af Larsens sproglige udtryk, skal man bestemt ikke lade sig frustrere af. Kapitlerne tjener både som forskellige aspekter ved feltet og som tilgange til problematikkerne; de er kort sagt grundelementerne i kartografien.

De første kapitler består af de delvist indledende filosofiske diskussioner med udgangspunkt i bl.a. John Searle og Ludwig Wittgenstein. De forskellige tænkere, der inddrages, anvendes til at frembringe et nuanceret billede af en mulig filosofisk tilgang til hjernen. Larsen har især fokus på at overskride dualismen mellem den fysiske hjerne og ånden samt på at undgå enhver form for reduktionisme, der kun viser sig begrænsende og fattig på filosofisk udbytte.

Bogens midterste del består af en kort (måske også for kort) gennemgang af Vesterlandets opfattelse af hjernen i et kultur- og videnskabshistorisk lys og er primært interessant, hvad angår skitseringen af nutidens forståelse af hjernen, samt videnskabshistorikeren Michael Hagners begreb Homo cerebralis. Ydermere gennemgås førnævnte Leslie Brothers' og sociologen Nikolas Roses Foucaultinspirerede tanker om subjektet og hvad man kunne kalde biomedicinsk magt som optakt til Larsens egen samtidsdiagnostik.

Kapitel 9 er både den vigtigste og vægtigste del af bogen, da Larsen her udfolder sin samtidsdiagnostik. Der tages udgangspunkt i hjernen som en plastisk enhed - sådan som den nyeste hjerneforskning opfatter den; som noget biologisk, der kan (og bør) udvikles og formes på et dynamisk grundlag. Som det hedder i bogens undertitel, er der tale om den plastiske hjernes æra, hvor den dominerende neurovidenskab, gennem forståelsen af hjernen som dynamisk og formelig, udvider sit videnskabelige felt ved at kunne henvise 
alt til at influere denne plastiske hjerne. Neurovidenskaben er på den vis blevet "alt-annekterende" og præfixet "neuro-" knopskyder videnskaberne.

Opfattelsen af hjernen som plastisk har samme knopskydende effekt i samfundet og får afgørende betydning for menneskets selvforståelse og rolle i samfundet. Kapitlets samtidsdiagnostik indeholder interessante overvejelser både i forhold til menneskets forhold til sig selv som biologi og som eksistens og i forhold til de biopolitiske magt- og kapitalinteresser, der udfolder sig over for det moderne individ - især sidstnævnte aspekt bærer teoretisk præg af Michel Foucault, Pierre Bourdieu og Gilles Deleuze i samspil.

Efter samtidsdiagnosen vender Larsen tilbage til det filosofiske hovedærinde omkring filosofiens vigtige rolle. I introduktionen optegnes fire forskellige måder, hvorpå man kan karakterisere filosofiens forhold til videnskaben: Filosofien kan fungere som enten a) bedrevidende overdommer, b) ekskluderet medlem, c) service-minded sparringspartner eller d) intervenerende kritiker.

Larsen argumenterer stærkt for at filosofien skal fungere som kritik (d) - en kritik der synes deleuziansk inspireret, da den både er ind- og angribende, men også nyskabende (en tone, der i øvrigt er gennemgående i skriftet). Samtidig er det vigtigt at undgå den filosofiske arrogance, selvom f.eks. begrebslige afklaringer stadig er vigtige (a), og at undgå en rolle som en nyttig service-medarbejder, om end dialog selvfølgelig stadig er ønskelig (c). Den forviste og bortdømte filosofi (b) kommer Larsen ikke rigtig omkring til at redde, men dette er $\mathrm{i}$ mine øjne ikke hans skyld. Neurovidenskaben kan fortsat ignorere filosofien (inkl. Larsens eget skrift), hvis den vil - for den har vind i sejlene, får bevilget masser af penge og har travlt med at få møbleret de seneste "annekser". Men Larsen opfordrer filosofiens verden til at være insisterende og påtrængende, og "lave rav i den" hos neurovidenskaben med ordentlig, kritisk filosofi - f.eks. kritiske undersøgelser af “...den omsiggribende tvang, hang og trang til at tænke og tro, at hjerneforskningen kan fortælle os, hvem vi faktisk er..." (s.7).

Samtidig tilbyder han et kort over feltet med en skitseret rute, man enten kan følge - eller nøjes med at studere. Bogens samtidsdiagnose understreger imidlertid vigtigheden af at følge op på Larsens opfordring om kritisk intervention i samtidens tendenser, da hjerneforskningen har vidtrækkende konsekvenser for individ, kultur og samfundspolitik. Og for 
filosofien selv. Bogen slutter med at skitsere nogle figurer over problematikkernes spændingsfelter, der vil kunne benyttes som inspiration til udforskning af videre problemstillinger.

Måske skal Steen Nepper Larsens bog først og fremmest ses som dette sidste, nemlig som inspiration. Om teserne holder stik er ikke det afgørende og heller ikke bogens projekt; den er et slags arbejdspapir, et supplement til en forskningsproces, der både vækker tanken og på fin vis introducerer dette felt. Et felt, der er interessant i sig selv, men som faktisk også kunne fungere som kulisse for en moderne genopsætning af gamle filosofiske klassikere som f.eks. Hvad er ånd?

ANJA SKAAR JACOBSEN

\section{Den sidste kantianer}

Dan Charly Christensen: Naturens tankelaser: En biografi om Hans Christian Ørsted, 2 bd., Museum Tusculanum, 2009, 1209 sider, 498,- kr.

Hans Christian Ørsted (17771851) er en af de største danske naturvidenskabsmænd nogensinde. Besiddende en magtfuld post som ualmindelig initiativrig professor ved universitetet var han allerede verdensberømt i Køben- havn, længe inden han opdagede elektromagnetismen i 1820. Opdagelsen udødeliggjorde med ét slag hans navn i videnskabshistorien. Undertiden møder man den holdning, at elektromagnetismen bare var et fænomen Ørsted tilfældigt faldt over midt under en forelæsning. Derudover er det en udbredt opfattelse, at Ørsted ikke lavede noget af betydning efter han havde gjort denne opdagelse. En lignende holdning kan man støde på vedrørende den store danske astronom Tycho Brahe; Brahe's videnskabelige bidrag reduceres undertiden til hans model for solsystemet, som så oven i købet ikke regnes for betydningsfuld, da den jo ikke ramte "rigtigt". Sådanne reaktioner kan være udtryk for uvidenhed om naturvidenskabens udvikling, praksis og historiske betingelser gennem tiderne. Videnskabelige resultater (og videnskabsmænds og -kvinders virke) skal ses og vurderes $i$ sammenhæng med den tid de blev fremsat i. Og i det mindste videnskabshistorisk set er vi for længst kommet ud over den tid, hvor naturvidenskab blev reduceret til dens produkter alene, $i$ form af opdagelser og teorier.

$\mathrm{Nu}$ har Dan Charly Christensen begået en mesterlig biografi om Ørsted, der til fulde må rette op på sådanne misforståelser om denne for det meste retskafne mand, hans 